\title{
Chemoprophylaxis in Colorectal Cancer: Current Concepts and a Practical Algorithm for Use
}

\author{
Authors \\ Victoria P. Y. Tan \\ Pierre Chan \\ Ivan F.N. Hung \\ Roberta Pang \\ Benjamin C. Y. Wong
}

\begin{abstract}
Affiliations
Department of Medicine and Center for Cancer Research, University of Hong Kong, Queen Mary Hospital, Hong Kong
\end{abstract}

\section{Corresponding Author}

Professor Benjamin C.Y. Wong

Department of Medicine, University of Hong Kong, Queen Marry Hospital, Hong Kong Email: bcywong@hku.hk

Telephone number: (852) 2855-4049

Fax number: (852) 2904-9443 


\section{Abstract}

Background: Colorectal cancer (CRC) is the second most common lethal cancer in the Western world. There is a 10 to 20 years lead time from normal mucosa to carcinoma which offers a window of opportunity to modify and prevent the outcome of CRC, with its incipient morbidity and mortality.

Objective: To review the evidence for chemoprophylaxis in CRC, identify currently utilized agents and determine their role in the current management algorithm of CRC. Methods: Review of large cohort-control and randomized controlled trials in the most studied chemoprophylaxis agents.

Results/conclusion: Currently, the role for chemoprophylaxis in CRC remains a niche area, celecoxib is the only recommended agent for utilization in patients with familial polyposis syndromes. However, the role of chemoprophylaxis is likely to grow significantly in the next decade as understanding of the stepwise tumorigenesis cascade becomes better understood and currently conducted clinical trials are completed.

\section{Keywords}

Chemoprophylaxis, Chemoprevention, Colo-Rectal Carcinoma, Adenoma, Adenomatous Polyps, COX-2 Inhibitors, NSAIDS, Vitamin D, Calcium, 5-ASA

\section{Introduction}

\subsection{Epidemiology}

Colorectal cancer (CRC) is the second most common lethal cancer after lung cancer ${ }^{1}$, accounting for 55,000 deaths per year in the United States and its incidence is rapidly rising in Asia ${ }^{2}$. Overall, the incidence of CRC in Asian countries including Hong Kong, Singapore, Japan and Korea is approaching that of the West ${ }^{2}$. The detection rate of advanced neoplasms is between $4.5-7.8 \%$ in both Asian and Western populations. ${ }^{3-6}$ However, despite a declining mortality rate for CRC in the West, Asia is observing a rising mortality ${ }^{2}$. Thus, CRC is a widely prevalent disease associated with considerable mortality and morbidity in both the East and West.

The reason for the rising incidence of CRC in Asia and the high rate seen in the West is clearly related to a complex interplay between genetics and the environment. The adoption of the 'westernized lifestyle' which includes a diet high in fat and protein but low in fibre ${ }^{2}$ is cited as a cause of CRC development. However the influence of family history $^{3}$ and racial differences seen between different ethnic communities in Asia underscore the influence of genetic factors in the etiology of CRC development. In countries like Singapore and Malaysia where the ethnic population consists of Chinese, Malay and Indians, the incidence of CRC is consistently lower in Indians and Malays than among the Chinese ${ }^{2,4}$. Overall, studies in Asia have found that Japanese, Chinese 
and Koreans have a higher incidence of advanced neoplasms compared to other Asians ${ }^{3 \text {, }}$ 4.

\subsection{Adenoma Carcinoma Sequence}

Unlike lung cancer, CRC is one of the most preventable cancers, due to the long lead times involved in the step-wise progression from normal mucosa to adenomatous polyp to carcinoma, and the therapeutic interventions including colonoscopy available to definitively treat adenomas prior to malignant change. Polypectomies to remove adenomas during screening colonoscopies may lower the mortality rate from CRC by as much as $30-40 \%{ }^{5}$

The natural evolution of normal mucosa to adenomatous polyp to overt carcinoma, spans on average 10-20 years ${ }^{6}$. This long lead time presents an opportunity in terms of providing a window of opportunity for prevention and intervention; however it also complicates the study of the impact of pharmacological agents, necessitating studies of considerable duration and patient size to detect a significant effect. Thus as the epidemiology of adenomas closely resembles that of CRC itself, ${ }^{78}$ prevention of adenomas has been used as a surrogate end-point as it is reasoned that preventing adenomas will most likely also prevent CRC.

\subsection{Risk Factors in CRC Development}

Many of the risk factors associated with CRC development including age, sex, ethnicity and family history are not modifiable. Older age particularly over the age of 50 is associated with an accelerated rate of CRC development ${ }^{9,10}$, hence the current recommendation is that CRC screening commences at the age of 50 in an average risk individual ${ }^{11,12}$. Consistently, the incidence of CRC development in males is higher than females $^{2,9}$, moreover a study found that pregnancy was associated with a reduced risk of CRC, leading to a hypothesis that female sex hormones may be protective factor for CRC development $^{2,13}$. As previously mentioned, Japanese, Korean and Chinese ethnic groups have a higher incidence of CRC when compared to other Asians, even when the ethnic population resides in the same country ${ }^{4,14,15}$. Finally, a positive family history confers increased risk of CRC development. A prospective study showed that the age adjusted risk for CRC in a person with an affected first degree relative is $1.72^{16}$. A meta-analyses of 27 case-control studies found that first degree relatives of patients with CRC have an increased risk of colon cancer of $2.42{ }^{17}$ and the relative risk is increased to more than 5 fold if the index case is under 45 years ${ }^{2,18}$.

Modifiable risk factors include obesity, smoking and ethanol intake. A meta-analyses found a relative risk of CRC of 1.37 for overweight and obese men ${ }^{18}$, probable causative factors cited include hyper-insulinaemia and the role of oxidative stress initiated by hypergycaemia. ${ }^{9}$ Smoking increases the risk of CRC, more so for rectal cancers than for colon cancer where the risk is between 1.43-2.64 depending on the number of cigarettes 
per day ${ }^{19}$. Ethanol intake of more than 7 standard drinks per week was associated with an increased risk of CRC of 1.72 , moreover the increased risk of smoking and ethanol intake was additive ${ }^{19}$. Despite the plethora of detrimental health effects caused by obesity, smoking and excess ethanol and despite public health campaigns to raise awareness, the prevalence of these modifiable CRC risk factor continues to grow, with some even calling the global rise in obesity an epidemic.

\subsection{CRC and health seeking behaviour}

CRC screening via facial occult blood testing, flexible sigmoidoscopy and colonoscopy ${ }^{2}$ is the cornerstone of prevention. However its efficacy is limited due to low compliance with screening guidelines. In the United States, Canada, Europe and Australia, there is widespread scientific recognition of the value of CRC screening and there are national guidelines which support the screening program. Despite this, access to colonoscopic polypectomy is not yet widely available even in developed countries ${ }^{20}$ and even when available, the uptake of screening for CRC in those eligible remains poor ${ }^{2}$. In Japan, only $17 \%$ of the eligible population underwent screening ${ }^{21}$, whereas in the West, eligible uptake rates were consistently less than $50 \%$ (see Table 1). Even in patients with a family history of CRC, a study found that of patients with positive genetic testing $71 \%$ of patients had a screening colonoscopy within 12 months of diagnosis ${ }^{22}$ In Asia, only several countries including Singapore, Japan, Taiwan, Korea and Australia have a national guideline regarding CRC screening, and overall governmental financial and general support for CRC is very limited. So it is not surprising the rates of screening are low ${ }^{2}$. Despite the significant development of diagnostic and therapeutic tools to detect and treat pre-cancerous lesions in the colon and rectum, there are significant barriers to screening both in an average risk population and in higher risk patients, hence the need for the role of chemoprophylaxis in CRC to emerge.

\section{Aim of Chemoprophylaxis}

Chemoprophylaxis is a concept in the prevention of CRC which aims to interfere with the process of carcinogenesis by the targeting of key molecular pathways via pharmacologic agents to prevent, arrest or cause regression of adenomas, which are presumed to be precursors to CRC. Chemoprophylaxis can be utilized in a number of population cohorts. Chemoprophylaxis may be given as primary prevention, either to patients with average risk of CRC or only to those selected population sub-groups at higher risk of CRC, including relatives of patients with familial polyposis coli syndromes, or CRC. Chemoprophylaxis may also be utilized as secondary prevention, whereby it should be utilized in conjunction with CRC screening in patient sub-groups such as patients with detected adenomatous polyps, a prior history of CRC and family members of patients with CRC. The ideal chemoprophylaxis agent should be potent, inexpensive, widely available, and suitable to long term administration and most importantly, free from serious side effects. 


\subsection{Chemoprophylaxis Candidates \& Mechanism of Action}

The 10-20 years lead time in the development of CRC provides a window during which chemoprophylaxis may be utilized. However, it also complicates the studies of emergent pharmacologic agents, as treatment may have to be given for prolonged periods of time, particularly for primary prevention, before a therapeutic effect may or may not be seen. Moreover, large numbers of patients would need to be involved with prolonged follow-up which incurs problems such as escalating drop-out rates over time. Finally, studied patients would be subjected to additional risk involved with surveillance colonoscopies and polypectomies. The bulk of current evidence in chemoprophylaxis lies in studies of secondary prevention of either CRC or adenomas which require a shorter period of follow-up to assess the effect of chemoprophylaxis ${ }^{23,24}$.

A large number of agents have been identified as potential chemoprophylaxis agents, predominantly from findings of observational studies. However, the results of most adenoma primary prevention trials have been disappointing. Studies of antioxidant vitamins ${ }^{25}$, fiber ${ }^{26}$, diet ${ }^{24}$ (median follow-up 3 years) and hormone replacement therapy ${ }^{27}$, conducted in average-risk populations have all been negative. The apparent discordance between the findings of observational studies and the concomitant randomized controlled studies is explainable by the fact that the former are more prone to confounding and bias than the latter, ${ }^{28}$ especially with regard to the assessment of preventive behaviors that may be difficult to detect and control for. Studies of chemoprophylaxis in the secondary prevention of adenomas or CRC have yielded better results. The best studied agents include Vitamin $\mathrm{D}$ and calcium, non-steroidal antiinflammatory drugs (NSAIDS) and cyclo-oxygenase 2 inhibitors (COX-2).

\subsection{Calcium \& Vitamin D}

The focus on calcium and Vitamin D as possible chemoprophylaxis agents in CRC came from observational studies which revealed an inverse relationship between calcium and vitamin D intake with risk of CRC ${ }^{29-32}$ and recurrent polyps. ${ }^{33,34}$. The mechanisms underlying calcium's anti-carcinogenic effects in the large bowel are not clear. One hypothesis is based on its capability to bind to and precipitate bile acids and soluble fatty acids, rendering them relatively inert in the bowel lumen ${ }^{35,36}$, whereas more recent studies suggest that extra cellular calcium can affect cell proliferation and differentiation via the calcium sensing receptor, a cell surface receptor that is expressed both in normal colon and colon cancer cell lines ${ }^{37-39}$. With regard to vitamin $\mathrm{D}$, in vitro and in vivo studies have shown that vitamin D and vitamin D analogs can inhibit cell proliferation, induce differentiation, and promote apoptosis ${ }^{40-42}$.

Primary prevention of CRC through treatment with calcium and/or vitamin D has yielded results which generally show a reduction of CRC. ${ }^{43}{ }^{44}$ (see Table 2). A large randomized, double-blind, placebo-controlled trial involving over 30,000 postmenopausal women treated with calcium and vitamin D (dose 200IU twice daily) versus placebo for an 
average of 7.0 years found the incidence of invasive colorectal cancer did not differ significantly between women assigned to calcium plus vitamin D supplementation and those assigned to placebo, hazard ratio 1.08 (95\% confidence interval (CI), 0.86 to 1.34, $\mathrm{P}=0.51)^{43}$. The ongoing 5 year extension follow-up will assess the longer-term effect of this intervention, as 7 years may not have been sufficient time to demonstrate the effect of calcium and vitamin $\mathrm{D}^{43}$ however the longer follow-up time may or may not result in a different outcome as the dose of Vitamin $\mathrm{D}$ given to the study patients is lower than the dose usually utilised for CRC prevention ${ }^{45}$. However a pooled analysis of 10 cohort studies, a comprehensive analysis involving 534,536 patients, assessed dietary consumption and total calcium intake (diet plus supplements) supported a reduction in the incidence of colorectal cancer of 10 to 15 percent. $^{44}$, the relative risk for the highest versus the lowest quintile of intake was $0.86(95 \% \mathrm{CI}=0.78$ to $0.95 ; \mathrm{P}($ trend $)=.02)$

More recently, two studies from Japan have found positive associations between calcium and/or vitamin D intake and lowering of the risk of CRC. Mizoue et al's study found that the odds ratio for the highest versus the lowest quintile for calcium intake was 0.64 (95\% confidence interval, 0.45-0.93). Higher levels of dietary vitamin D were significantly associated with decreased risk of colorectal cancer among those who had fewer chances of sunlight exposure at work or in leisure (P for trend $=0.02$ ) ${ }^{46}$. Ishihara et al's group undertook a prospective cohort study involving 74, 639 patients and found the multivariate hazard ratio in the highest quintile of dietary calcium intake compared with the lowest was 0.71 (95\% CI: 0.52, 0.98) among men. No association was seen for Vitamin D intake ${ }^{47}$.

For secondary prevention, randomized clinical trials that found that calcium supplementation lowered the incidence of recurrent colorectal polyps to some degree ${ }^{48,49}$, with one report demonstrating that this protection was confined to subjects with higher endogenous vitamin D levels. ${ }^{50}$

Previous trials demonstrating beneficial effects of calcium and/or vitamin D supplementation in CRC prevention, have led to the use of these agents in risk-reduction strategies. However, the benefits of primary prevention are mildly positive and for secondary prevention, the reductions have only been in the development of recurrent adenomas, the surrogate marker for development of CRC.

\section{Amino-Salicylates}

The protective association between 5-aminosalicylates (5-ASA) and CRC emerged from observations of patients with inflammatory bowel disease (IBD), particularly ulcerative colitis (UC) who were treated with 5-ASA. The mechanism by which 5-ASA exerts its chemoprotective effect is unclear at present although protean mechanisms have been suggested. Proposed mechanisms include 5-ASA's anti-inflammatory action on the bowel, action as a free-radical scavenger and it's improvement of cellular replication fidelity amongst others ${ }^{51} 52$.

5-ASA has been extensively studied in the reduction of CRC only in patients with IBD, in particular UC. A recent meta-analysis of 9 observational studies (3 cohort, 6 case- 
control) involving a total of 1,932 subjects with UC found a protective association between the regular use of 5-aminosalicylates and CRC (OR=0.51; 95\% confidence interval (CI): 0.37-0.69) and a combined endpoint of CRC/dysplasia (OR 0.51; 95\% CI: $0.38-0.69)^{53}$. A large nested case-control study involving 18,969 patients with IBD also supports the meta-analysis finding that regular 5-ASA usage dramatically reduced the risk of CRC compared to irregular usage (Adjusted OR 0.60; 95\% CI 0.38-0.96) ${ }^{54}$ as do a number of smaller studies 5556 .

Unfortunately, at present further studies are needed before 5-ASA could be recommended to be utilised as chemo-prophylactic agent, both in the IBD and general populace. Questions which will need to be answered include the optimal dose of 5-ASA, whether all 5-ASA are equal in their effect and finally, the role of 5-ASA when patients are already stabilized on an alternate agent including azathioprine ${ }^{53}$.

\subsection{Non-Steroidal Anti-Inflammatory Drugs}

The suggestion of NSAIDS as possible chemoprophylaxis arose from the consistent concordance of data from more than 40 observational studies suggesting that NSAIDS reduce the incidence of colorectal adenomas, colorectal cancer, and deaths from colorectal cancer ${ }^{57}$. A leading hypothesis explaining the mechanism of NSAIDS in preventing CRC and adenomas is based on the presence of tumorigenic COX -2 within adenomas but not in normal intestinal tissue. COX-2 mediates the production of prostaglandin E2 (PGE2) in epithelial tissues, resulting in activation of signaling pathways that promote cell proliferation and inhibit cell death ${ }^{58,59}$. COX-2 is over expressed in $40-50 \%$ of adenomas and $85 \%$ of CRC ${ }^{60}$. NSAIDS, which includes sulindac and aspirin, the two most studied NSAIDS as CRC chemoprophylactic agents, are non selective cyclo-oxygenase inhibitors (see Table 2). Emergent evidence suggest sulindac may exert it chemoprophylactic action via mechanisms other than via COX-2 ${ }^{61}$

Sulindac, a nonselective cyclooxygenase inhibitor, was previously reported to cause complete or nearly complete regression of rectal adenomas in uncontrolled studies ${ }^{62-65}$, and in a small, placebo-controlled, drug-crossover trial of patients with familial adenomatous polyposis ${ }^{65}$. Regression of rectal adenomas, though of lesser magnitude, was reported in two subsequent placebo-controlled studies ${ }^{3}{ }^{66}$ However, rapid recurrence of adenomas was observed from three months after discontinuation of drug therapy ${ }^{3,65}$ and evidence of long-term efficacy of sulindac is still lacking, with case reports of tumor progression in patients receiving sulindac ${ }^{67}$.

Randomized trials of aspirin demonstrated substantial chemopreventive effect in secondary prevention, with reductions of approximately 20-50 percent among patients in whom recurrent adenomas developed. ${ }^{23,68,69}$ Aspirin was also associated with more substantial reductions in the risk of advanced lesions than in that of non-advanced lesions suggests that the effects of aspirin may be greater in later stages of the adenomacarcinoma sequence ${ }^{68}$. These findings are tempered somewhat by the observation in one study that low-dose, but not high dose, aspirin had an antitumor effect ${ }^{68}$. There was an increase in the risk of stroke among patients who were randomly assigned to receive 
aspirin $(\mathrm{P}=0.06)$, a finding consistent with previous studies of populations at low cardiovascular risk ${ }^{68}$.

The sulindac and aspirin studies have had generally consistent results, with benefits after factors including age, race, sex, and location of the tumor in the colon or the rectum have been controlled for, however, the gastrointestinal toxicity associated with NSAIDS at large may limit their long-term use for cancer prevention ${ }^{70}$. Almost all studies indicate that the reduction in the risk of colorectal cancer or adenomas declines after aspirin therapy is stopped ${ }^{71}$.Long-term studies, as well as direct comparisons of selective and nonselective cyclooxygenase inhibition, could further define the relative clinical benefits and adverse effects of these agents so that NSAID place in the management of CRC may be further clarified ${ }^{72}$.

\subsection{Cyclo-Oxygenase-2 Inhibitors}

Selective COX-2 inhibitors were developed as a safer alternative to nonselective NSAIDs, with respect to gastrointestinal bleeding, for the treatment of pain and inflammation. These agents preferentially inhibit COX-2, an inducible enzyme mediating inflammation and tumorigenesis, and not COX-1, the constitutively expressed enzyme responsible for protective mechanisms in the gastric mucosa and renal vasculature. Selective COX-2 inhibitors have fewer effects on gastric mucosa or platelet function than do the nonselective NSAIDs and, as a result, may be associated with fewer ulcers and hemorrhagic complications ${ }^{74}$. COX-2 inhibitors may also have effects on other enzymes, such as induction of 15-lipoxygenase-1 expression which could mediate its biologic effects $^{75}$. The best studied COX-2 inhibitors to date include celecoxib and rofecoxib (see Table 2).

It was noted that in patients with familial adenomatous polyposis (FAP), celecoxib showed antitumor activity, with regression, in addition to suppression of established adenomas $^{72}$. In a six-month study in patients with FAP, treatment with a celecoxib $400 \mathrm{mg}$ twice daily was associated with statistically significant $28 \%$ regression of colorectal adenomas as compared to a reduction of $4.5 \%$ in the placebo group $(p=0.003)^{72}$. Significant regression was not associated with the dose of $100 \mathrm{mg}$ twice daily ${ }^{72}$. These findings suggest that celecoxib could serve as an adjunct to current best management in the FAP syndromes by suppressing polyp formation in patients with residual rectum after total colectomy or in patients with an intact colon who are awaiting colectomy.

Three landmark studies on COX-2 inhibitors on sporadic adenomas have demonstrated the significant effect of COX-2 inhibitors on secondary CRC and/or adenoma prevention. The Adenomatous Polyp Prevention on Vioxx (AP-PROVe) trial utilizing rofecoxib, the Prevention of Sporadic Adenomatous Polyps (PreSAP) trial and the Adenoma Prevention with Celecoxib (APC) trial both utilizing celecoxib compared to placebo, found statistically significant reductions in recurrent adenomas in the treatment arm over placebo, and moreover found that a greater effect was observed in advanced adenomas ${ }^{75-}$ 78 . 
Tempering the significant impact of COX-2 inhibitors on the recurrence of adenomas are safety issues concerning COX-2 inhibitors. In both the APPROVe and APC studies there was a significant increase in cardiovascular events including myocardial infarction stroke, stroke and heart failure ${ }^{76}$.The potential addition of COX-2 inhibitors to an optimal endoscopic surveillance program must be weighed against the known risk of serious cardiovascular events ${ }^{76,78}$. In the APPROVe trial a total of 46 patients in the rofecoxib arm had a confirmed thrombotic event compared to 26 patients in the placebo group (RR, 1.96) ${ }^{76}$, whilst in the APC trial, a significant dose-response excess of major cardiovascular events for celecoxib 200mg and 400mg of 2.5 (95\% CI, 1.0-6.4) and 3.5 (95\% CI, 1.4-8.5) respectively ${ }^{78}$, lead to premature discontinuation of both studies. Secondary analysis of the APC study indicates that the risk was for those patients with a baseline history of atherosclerotic heart disease over a median on 3.1 years ${ }^{79}$. Interestingly the PreSAP trial which was also discontinued due to safety concerns did not find any statistically significant excess cardiovascular events in the active treatment arm with celecoxib ${ }^{75}$.

The studies of COX-2 are important as they demonstrate the relationship between COX-2 and colonic adenomas. COX-2 inhibition does have a place in the secondary prevention of CRC. At present, given the long term safety data of COX-2 inhibitors, celecoxib is the only approved agent for chemoprophylaxis in high risk patients with FAP ${ }^{6}$.

\section{Proof of Concept}

The place of chemoprophylaxis in CRC has been an area of interest for some time and provides a number of instructive points. Firstly, it demonstrates the importance of observational studies as flags to possible beneficial agents for prevention of CRC, but more importantly, this story highlights the absolute necessity to subject the findings of observational studies to rigorous randomized, controlled trials to determine the actual contribution of a proposed chemoprophylactic agent, consider anti-oxidant vitamins and hormone replacement therapy, whilst controlling for possible confounding factors. Secondly, it demonstrates the absolute necessity to demonstrate the safety of the ideal CRC chemoprophylaxis agent over the long term, as COX-2 inhibitors are safe over the short term when used as treatment for pain and inflammation and their long term safety issues have only come to light when utilized long term. Thirdly, the search for the ideal chemoprophylaxis agent has yielded a number of agents including calcium and vitamin D, aspirin, sulindac and celecoxib which could be used as an adjunct to currently employed screening methods, particularly given possibility of overlooked adenomas, since up to1525 percent of small polyps may be missed in a single colonoscopy ${ }^{80,81}$. 5-ASA's role as a chemoprophylaxis agent is at present unresolved. Finally, the search for the ideal chemoprophylaxis agent for CRC prevention has yielded further insight into the steps in tumourigenesis, mainly the proof of concept of the role of COX-2 in colonic adenoma development. 


\section{Conclusion}

With each iteration of studies in the quest for the ideal CRC chemoprophylaxis agent, more knowledge is generated about CRC and the process of tumourigenesis. Although current chemoprophylaxis agents are imperfect, it is evident that selected patients may benefit from usage of calcium and vitamin $\mathrm{D}$, aspirin and sulindac for secondary prevention of adenomas and/or CRC. In patients at high risk patients due to FAP, celecoxib is recommended. However, attention needs to be paid in balancing potential cardiovascular risk associated with COX-2 inhibitors. Newer chemoprophylaxis agents such as selenium, difluoromethylornithine and ursodexycholic acid ${ }^{27}$ are on the horizon and are currently under investigation. Combination chemoprophylactic therapies hold promise to herald in a new era of reduction in the morbidity and mortality associated with CRC.

\section{Expert opinion}

The role of chemoprophylaxis in the prevention of adenomas and ultimately CRC continues to evolve. Current utility is in the moderate to high risk populations which include patients with Familial Adenomatous Polyposis Coli and Hereditary NonPolyposis Colorectal Cancer or Lynch’s Syndrome (see figure 1). In these patients, appropriate screening/surveillance remains the cornerstone of management with prophylactic surgery an important therapeutic adjunct. Chemoprophylaxis utilising celecoxib is recommended as it has been shown to arrest and possibly cause the regression of adenomas that develop in the interim between lower gastro-intestinal endoscopies. However in patients with cardio-vascular risk factors and/or history sulindac should be substituted for celecoxib. For patients with moderate CRC risk, the benefits of chemoprophylaxis must be balanced with the likely adverse effects of the chemoprophylactic agent. In this group with moderate risk for CRC utilization of a chemoprophylactic agent which is able to treat other co-morbid conditions, strengthens the indications for use, in particular, the utilization of calcium with or without Vitamin D in a patient with osteoporosis, or aspirin in a patient with concomitant cardiovascular disease, would deliver increased mileage for the chemoprophylactic agent whilst mitigating the possible adverse effects. The exception being in patients with a detected advanced adenoma, here it would be reasonable to administer celecoxib until the next surveillance colonoscopy (usually within 3 years), to treat any synchronous adenomas that had been missed or only partially resected. In patients with average risk of CRC, there are a multitude of modalities over and above chemoprophylaxis which have been shown to decrease the risk of CRC (see Figure 2), the most important of which are to manage lifestyle factors and participate in CRC screening. Here, there needs to be a relatively high threshold for utilizing chemoprophylaxis because of the high risk of doing harm.

These are exciting times in the primary and secondary prevention of adenomas and CRC, the results from the Women's Health Initiative and the results of the newer chemoprophylatic agents may change the treatment paradigm of CRC within the next 10 years. 
Uptake of CRC Screening

Table 1

\begin{tabular}{|c|c|c|c|c|}
\hline Study & Country & CRC Screening & \% Uptake * & Year \\
\hline Myers et al $^{82}$ & USA & FOBT & $41 \%$ & 1993 \\
\hline Hardcastle et al & $\begin{array}{l}\text { United } \\
\text { Kingdom }\end{array}$ & FOBT & $38.2 \%$ & 1996 \\
\hline Robinson et al ${ }^{84}$ & $\begin{array}{l}\text { United } \\
\text { Kingdom }\end{array}$ & FOBT & $37.7 \%$ & 1996 \\
\hline Cole et al ${ }^{85}$ & Australia & FOBT & $32-40.7 \%$ & 2002 \\
\hline Seeff et al ${ }^{86}$ & USA & $\begin{array}{l}\text { FOBT and/or lower } \\
\text { GI endoscopy }\end{array}$ & $42.5 \%$ & 2004 \\
\hline Saito et al $^{21}$ & Japan & FOBT & $17 \%$ & 2006 \\
\hline $\begin{array}{l}\text { Zarychanski et } \\
\text { al }^{87}\end{array}$ & Canada & $\begin{array}{l}\text { FOBT and/or lower } \\
\text { GI endoscopy }\end{array}$ & $17.6-23.5 \%$ & 2007 \\
\hline $\begin{array}{l}\text { Deutekom et al } \\
88\end{array}$ & Netherlands & FOBT & $49 \%$ & 2009 \\
\hline
\end{tabular}

* proportion of patients who take up the CRC screening when eligible to do so ** self reported answer to questionnaire about screening for CRC

$\mathrm{CRC}=$ colorectal cancer

FOBT $=$ Faecal occult blood testing

Summary of Chemoprophylaxis Trial Outcomes

Table 2

\begin{tabular}{|c|c|c|c|c|c|c|c|}
\hline Study & Agent & $\begin{array}{l}\text { Type of } \\
\text { Prevention* }\end{array}$ & $\begin{array}{l}\text { Relative } \\
\text { Risk } \\
\text { Ratio }\end{array}$ & $\begin{array}{l}\text { Odds } \\
\text { Ratio }\end{array}$ & $\begin{array}{l}\text { Hazard } \\
\text { Ratio }\end{array}$ & $95 \% \mathrm{CI}$ & P-Value \\
\hline $\begin{array}{l}\text { Wactawski- } \\
\text { Wende et al }\end{array}$ & $\begin{array}{l}\text { Calcium + } \\
\text { Vitamin D }\end{array}$ & $\begin{array}{l}\text { Primary } \\
\text { CRC }\end{array}$ & & & 1.08 & $\begin{array}{l}0.86- \\
1.34\end{array}$ & 0.51 \\
\hline Baron et al ${ }^{48}$ & Calcium & $\begin{array}{l}\text { Secondary } \\
\text { Sporadic }\end{array}$ & 0.76 & & & $\begin{array}{l}0.6- \\
0.96\end{array}$ & 0.02 \\
\hline $\begin{array}{l}\text { Bonithon- } \\
\text { Kopp et al }\end{array}$ & Calcium & $\begin{array}{l}\text { Secondary } \\
\text { Sporadic }\end{array}$ & & 0.66 & & $\begin{array}{l}0.3- \\
1.17\end{array}$ & 0.17 \\
\hline Cho et al ${ }^{44}$ & Calcium & $\begin{array}{l}\text { Primary } \\
\text { CRC }\end{array}$ & 0.86 & & & $\begin{array}{l}0.78- \\
0.95\end{array}$ & 02 \\
\hline Grau et al ${ }^{50}$ & $\begin{array}{l}\text { Calcium + } \\
\text { Vitamin D } \\
\end{array}$ & $\begin{array}{l}\text { Secondary } \\
\text { Sporadic }\end{array}$ & $0.71 * *$ & & & $\begin{array}{l}0.57- \\
0.89\end{array}$ & 0.01 \\
\hline $\begin{array}{l}\text { Ishihara et al } \\
47\end{array}$ & $\begin{array}{l}\text { Calcium + } \\
\text { Vitamin D }\end{array}$ & $\begin{array}{l}\text { Primary } \\
\text { CRC }\end{array}$ & & & $0.71 \#$ & $\begin{array}{l}0.52- \\
0.98 \#\end{array}$ & \\
\hline$\underset{46}{\text { Mizoue et al }}$ & $\begin{array}{l}\text { Calcium + } \\
\text { Vitamin D }\end{array}$ & $\begin{array}{l}\text { Primary } \\
\text { CRC }\end{array}$ & $0.64 \# \#$ & & & $\begin{array}{l}0.45- \\
0.93 \# \#\end{array}$ & \\
\hline $\begin{array}{l}\text { Giardiello et } \\
\text { al }{ }^{3}\end{array}$ & Sulindac & FAP & 0.56 & & & & 0.01 \\
\hline
\end{tabular}




\begin{tabular}{|c|c|c|c|c|c|}
\hline $\begin{array}{l}\text { Sandler et al } \\
23\end{array}$ & Aspirin & $\begin{array}{l}\text { Secondary } \\
\text { CRC }\end{array}$ & 0.65 & $\begin{array}{l}0.46- \\
0.91\end{array}$ & \\
\hline Baron et al ${ }^{68}$ & $\begin{array}{l}\text { Aspirin } \\
\text { 81mg } \\
\text { Aspirin } \\
325 \mathrm{mg}\end{array}$ & $\begin{array}{l}\text { Secondary } \\
\text { Sporadic }\end{array}$ & $\begin{array}{l}0.81 \\
0.96\end{array}$ & $\begin{array}{l}0.6-0.96 \\
0.8-1.13\end{array}$ & \\
\hline $\begin{array}{l}\text { Benamouzig } \\
\text { et al } 69\end{array}$ & Aspirin & $\begin{array}{l}\text { Secondary } \\
\text { Sporadic }\end{array}$ & 0.73 & $\begin{array}{l}0.52- \\
1.04\end{array}$ & 0.08 \\
\hline Arber et al ${ }^{75}$ & Celecoxib & $\begin{array}{l}\text { Secondary } \\
\text { Sporadic }\end{array}$ & 0.64 & $\begin{array}{l}0.56- \\
0.75 \\
\end{array}$ & $<0.001$ \\
\hline Baron et al ${ }^{77}$ & Rofecoxib & $\begin{array}{l}\text { Secondary } \\
\text { Sporadic }\end{array}$ & 0.76 & $\begin{array}{l}0.69- \\
0.83\end{array}$ & $<0.0001$ \\
\hline $\begin{array}{l}\text { Bertagnolli et } \\
\text { al } 78\end{array}$ & $\begin{array}{l}\text { Celecoxib } \\
\text { 200mg } \\
\text { Celecoxib } \\
400 \mathrm{mg}\end{array}$ & $\begin{array}{l}\text { Secondary } \\
\text { Sporadic }\end{array}$ & $\begin{array}{l}0.67 \\
0.55\end{array}$ & $\begin{array}{l}0.59- \\
0.77 \\
0.48- \\
0.64\end{array}$ & $\begin{array}{l}<0.001 \\
<0.001\end{array}$ \\
\hline
\end{tabular}

* Refers to Primary or Secondary prevention of CRC and/or adenomas, FAP, CRC or sporadic denotes whether the study population was confined to patients with Familial Adenomatous Polyposis, prior history of Colorectal Carcinoma, or sporadic adenomas respectively

** Only for patients with Vitamin D levels above the median 29.1ng/ml \# Hazard ratio and CI refers to calcium in male study patients, no association seen between Vitamin D and a reduction in CRC development \#\# Odds ratio and CI refers to calcium, association also seen study patients with higher vitamin $\mathrm{D}$ intake or sunlight exposure $\mathrm{p}=$ for trend 0.02

\section{References:}

1. Boyle P, Ferlay J. Cancer incidence and mortality in Europe, 2004. Ann Oncol 2005;16:481-8.

2. $\quad$ Sung JJ, Lau JY, Young GP, et al. Asia Pacific consensus recommendations for colorectal cancer screening. Gut 2008;57:1166-76.

3. Giardiello FM, Hamilton SR, Krush AJ, et al. Treatment of colonic and rectal adenomas with sulindac in familial adenomatous polyposis. N Engl J Med 1993;328:1313-6.

4. Bae JM, Jung KW, Won YJ. Estimation of cancer deaths in Korea for the upcoming years. J Korean Med Sci 2002;17:611-5.

5. Selby JV, Friedman GD, Quesenberry CP, Jr., Weiss NS. A case-control study of screening sigmoidoscopy and mortality from colorectal cancer. N Engl J Med 1992;326:653-7. 
6. Arber N, Levin B. Chemoprevention of colorectal neoplasia: the potential for personalized medicine. Gastroenterology 2008;134:1224-37.

7. Peipins LA, Sandler RS. Epidemiology of colorectal adenomas. Epidemiol Rev 1994;16:273-97.

8. Neugut AI, Jacobson JS, De Vivo I. Epidemiology of colorectal adenomatous polyps. Cancer Epidemiol Biomarkers Prev 1993;2:159-76.

9. $\quad$ Sung JJ, Chan FK, Leung WK, et al. Screening for colorectal cancer in Chinese: comparison of fecal occult blood test, flexible sigmoidoscopy, and colonoscopy. Gastroenterology 2003;124:608-14.

10. Choe JW, Chang HS, Yang SK, et al. Screening colonoscopy in asymptomatic average-risk Koreans: analysis in relation to age and sex. J Gastroenterol Hepatol 2007;22:1003-8.

11. US Preventive Services Task Force et al. Screening for colorectal cancer: recommendation and rationale. Am Fam Physician 2002;66:2287-90.

12. Winawer S, Fletcher R, Rex D, et al. Colorectal cancer screening and surveillance: clinical guidelines and rationale-Update based on new evidence. Gastroenterology 2003;124:544-60.

13. Tamakoshi K, Wakai K, Kojima M, et al. A prospective study of reproductive and menstrual factors and colon cancer risk in Japanese women: findings from the JACC study. Cancer Sci 2004;95:602-7.

14. Leung WK, Ho KY, Kim WH, et al. Colorectal neoplasia in Asia: a multicenter colonoscopy survey in symptomatic patients. Gastrointest Endosc 2006;64:751-9.

15. Byeon JS, Yang SK, Kim TI, et al. Colorectal neoplasm in asymptomatic Asians: a prospective multinational multicenter colonoscopy survey. Gastrointest Endosc 2007;65:1015-22.

16. Fuchs CS, Giovannucci EL, Colditz GA, Hunter DJ, Speizer FE, Willett WC. A prospective study of family history and the risk of colorectal cancer. N Engl J Med 1994;331:1669-74.

17. Johns LE, Houlston RS. A systematic review and meta-analysis of familial colorectal cancer risk. Am J Gastroenterol 2001;96:2992-3003.

18. Dai Z, Xu YC, Niu L. Obesity and colorectal cancer risk: a meta-analysis of cohort studies. World J Gastroenterol 2007;13:4199-206.

19. Tsong WH, Koh WP, Yuan JM, Wang R, Sun CL, Yu MC. Cigarettes and alcohol in relation to colorectal cancer: the Singapore Chinese Health Study. Br J Cancer 2007;96:821-7.

20. Seeff LC, Shapiro JA, Nadel MR. Are we doing enough to screen for colorectal cancer? Findings from the 1999 Behavioral Risk Factor Surveillance System. J Fam Pract 2002;51:761-6.

21. Saito H. Colorectal cancer screening using immunochemical faecal occult blood testing in Japan. J Med Screen 2006;13 Suppl 1:S6-7.

22. Collins V, Meiser B, Gaff C, St John DJ, Halliday J. Screening and preventive behaviors one year after predictive genetic testing for hereditary nonpolyposis colorectal carcinoma. Cancer 2005;104:273-81.

23. Sandler RS, Halabi S, Baron JA, et al. A randomized trial of aspirin to prevent colorectal adenomas in patients with previous colorectal cancer. N Engl J Med 2003;348:883-90. 
24. Schatzkin A, Lanza E, Corle D, et al. Lack of effect of a low-fat, high-fiber diet on the recurrence of colorectal adenomas. Polyp Prevention Trial Study Group. N Engl J Med 2000;342:1149-55.

25. Greenberg ER, Baron JA, Tosteson TD, et al. A clinical trial of antioxidant vitamins to prevent colorectal adenoma. Polyp Prevention Study Group. N Engl J Med 1994;331:141-7.

26. Alberts DS, Martinez ME, Roe DJ, et al. Lack of effect of a high-fiber cereal supplement on the recurrence of colorectal adenomas. Phoenix Colon Cancer Prevention Physicians' Network. N Engl J Med 2000;342:1156-62.

27. Chlebowski RT, Wactawski-Wende J, Ritenbaugh C, et al. Estrogen plus progestin and colorectal cancer in postmenopausal women. N Engl J Med 2004;350:9911004.

28. Prentice RL, Langer R, Stefanick ML, et al. Combined postmenopausal hormone therapy and cardiovascular disease: toward resolving the discrepancy between observational studies and the Women's Health Initiative clinical trial. Am J Epidemiol 2005;162:404-14.

29. Flood A, Peters U, Chatterjee N, Lacey JV, Jr., Schairer C, Schatzkin A. Calcium from diet and supplements is associated with reduced risk of colorectal cancer in a prospective cohort of women. Cancer Epidemiol Biomarkers Prev 2005;14:126-32.

30. McCullough ML, Robertson AS, Rodriguez C, et al. Calcium, vitamin D, dairy products, and risk of colorectal cancer in the Cancer Prevention Study II Nutrition Cohort (United States). Cancer Causes Control 2003;14:1-12.

31. Terry P, Baron JA, Bergkvist L, Holmberg L, Wolk A. Dietary calcium and vitamin $\mathrm{D}$ intake and risk of colorectal cancer: a prospective cohort study in women. Nutr Cancer 2002;43:39-46.

32. Marcus PM, Newcomb PA. The association of calcium and vitamin D, and colon and rectal cancer in Wisconsin women. Int J Epidemiol 1998;27:788-93.

33. Peters U, Chatterjee N, McGlynn KA, et al. Calcium intake and colorectal adenoma in a US colorectal cancer early detection program. Am J Clin Nutr 2004;80:1358-65.

34. Kesse E, Boutron-Ruault MC, Norat T, Riboli E, Clavel-Chapelon F. Dietary calcium, phosphorus, vitamin D, dairy products and the risk of colorectal adenoma and cancer among French women of the E3N-EPIC prospective study. Int J Cancer 2005;117:137-44.

35. Sesink AL, Termont DS, Kleibeuker JH, Van der Meer R. Red meat and colon cancer: dietary haem-induced colonic cytotoxicity and epithelial hyperproliferation are inhibited by calcium. Carcinogenesis 2001;22:1653-9.

36. Van der Meer R, Lapre JA, Govers MJ, Kleibeuker JH. Mechanisms of the intestinal effects of dietary fats and milk products on colon carcinogenesis. Cancer Lett 1997;114:75-83.

37. Kallay E, Kifor O, Chattopadhyay N, et al. Calcium-dependent c-myc protooncogene expression and proliferation of Caco-2 cells: a role for a luminal extracellular calcium-sensing receptor. Biochem Biophys Res Commun 1997;232:80-3.

38. Chakrabarty S, Radjendirane V, Appelman H, Varani J. Extracellular calcium and calcium sensing receptor function in human colon carcinomas: promotion of E-cadherin expression and suppression of beta-catenin/TCF activation. Cancer Res 2003;63:67-71. 
39. Penman ID, Liang QL, Bode J, Eastwood MA, Arends MJ. Dietary calcium supplementation increases apoptosis in the distal murine colonic epithelium. J Clin Pathol 2000;53:302-7.

40. Palmer HG, Gonzalez-Sancho JM, Espada J, et al. Vitamin D(3) promotes the differentiation of colon carcinoma cells by the induction of E-cadherin and the inhibition of beta-catenin signaling. J Cell Biol 2001;154:369-87.

41. Cross HS, Pavelka M, Slavik J, Peterlik M. Growth control of human colon cancer cells by vitamin D and calcium in vitro. J Natl Cancer Inst 1992;84:1355-7.

42. Cross HS, Kallay E. Regulation of the colonic vitamin D system for prevention of tumor progression: an update. Future Oncol 2009;5:493-507.

43. Wactawski-Wende J, Kotchen JM, Anderson GL, et al. Calcium plus vitamin D supplementation and the risk of colorectal cancer. N Engl J Med 2006;354:684-96.

44. Cho E, Smith-Warner SA, Spiegelman D, et al. Dairy foods, calcium, and colorectal cancer: a pooled analysis of 10 cohort studies. J Natl Cancer Inst 2004;96:1015-22.

45. Gorham ED, Garland CF, Garland FC, et al. Vitamin D and prevention of colorectal cancer. J Steroid Biochem Mol Biol 2005;97:179-94.

46. Mizoue T, Kimura Y, Toyomura K, et al. Calcium, dairy foods, vitamin D, and colorectal cancer risk: the Fukuoka Colorectal Cancer Study. Cancer Epidemiol Biomarkers Prev 2008;17:2800-7.

47. Ishihara J, Inoue M, Iwasaki M, Sasazuki S, Tsugane S. Dietary calcium, vitamin D, and the risk of colorectal cancer. Am J Clin Nutr 2008;88:1576-83.

48. Baron JA, Beach M, Mandel JS, et al. Calcium supplements for the prevention of colorectal adenomas. Calcium Polyp Prevention Study Group. N Engl J Med 1999;340:101-7.

49. Bergsma-Kadijk JA, van 't Veer P, Kampman E, Burema J. Calcium does not protect against colorectal neoplasia. Epidemiology 1996;7:590-7.

50. Grau MV, Baron JA, Sandler RS, et al. Vitamin D, calcium supplementation, and colorectal adenomas: results of a randomized trial. J Natl Cancer Inst 2003;95:1765-71.

51. Allgayer $\mathrm{H}$. Review article: mechanisms of action of mesalazine in preventing colorectal carcinoma in inflammatory bowel disease. Aliment Pharmacol Ther 2003;18 Suppl 2:10-4.

52. Gasche C, Goel A, Natarajan L, Boland CR. Mesalazine improves replication fidelity in cultured colorectal cells. Cancer Res 2005;65:3993-7.

53. Velayos FS, Terdiman JP, Walsh JM. Effect of 5-aminosalicylate use on colorectal cancer and dysplasia risk: a systematic review and metaanalysis of observational studies. Am J Gastroenterol 2005;100:1345-53.

54. van Staa TP, Card T, Logan RF, Leufkens HG. 5-Aminosalicylate use and colorectal cancer risk in inflammatory bowel disease: a large epidemiological study. Gut 2005;54:1573-8.

55. Moody GA, Jayanthi V, Probert CS, Mac Kay H, Mayberry JF. Long-term therapy with sulphasalazine protects against colorectal cancer in ulcerative colitis: a retrospective study of colorectal cancer risk and compliance with treatment in Leicestershire. Eur J Gastroenterol Hepatol 1996;8:1179-83. 
56. Eaden J, Abrams K, Ekbom A, Jackson E, Mayberry J. Colorectal cancer prevention in ulcerative colitis: a case-control study. Aliment Pharmacol Ther 2000;14:145-53.

57. Hawk ET, Levin B. Colorectal cancer prevention. J Clin Oncol 2005;23:378-91.

58. Tsujii M, DuBois RN. Alterations in cellular adhesion and apoptosis in epithelial cells overexpressing prostaglandin endoperoxide synthase 2. Cell 1995;83:493-501.

59. Pai R, Soreghan B, Szabo IL, Pavelka M, Baatar D, Tarnawski AS. Prostaglandin E2 transactivates EGF receptor: a novel mechanism for promoting colon cancer growth and gastrointestinal hypertrophy. Nat Med 2002;8:289-93.

60. Eberhart CE, Coffey RJ, Radhika A, Giardiello FM, Ferrenbach S, DuBois RN. Up-regulation of cyclooxygenase 2 gene expression in human colorectal adenomas and adenocarcinomas. Gastroenterology 1994;107:1183-8.

61. Piazza GA, Keeton AB, Tinsley HN, et al. A novel sulindac derivative that does not inhibit cyclooxygenases but potently inhibits colon tumor cell growth and induces apoptosis with antitumor activity. Cancer Prev Res (Phila Pa) 2009;2:572-80.

62. Rigau J, Pique JM, Rubio E, Planas R, Tarrech JM, Bordas JM. Effects of longterm sulindac therapy on colonic polyposis. Ann Intern Med 1991;115:952-4.

63. Waddell WR, Loughry RW. Sulindac for polyposis of the colon. J Surg Oncol 1983;24:83-7.

64. Winde G, Schmid KW, Schlegel W, Fischer R, Osswald H, Bunte H. Complete reversion and prevention of rectal adenomas in colectomized patients with familial adenomatous polyposis by rectal low-dose sulindac maintenance treatment. Advantages of a low-dose nonsteroidal anti-inflammatory drug regimen in reversing adenomas exceeding 33 months. Dis Colon Rectum 1995;38:813-30.

65. Labayle D, Fischer D, Vielh P, et al. Sulindac causes regression of rectal polyps in familial adenomatous polyposis. Gastroenterology 1991;101:635-9.

66. Nugent KP, Farmer KC, Spigelman AD, Williams CB, Phillips RK. Randomized controlled trial of the effect of sulindac on duodenal and rectal polyposis and cell proliferation in patients with familial adenomatous polyposis. Br J Surg 1993;80:1618-9. 67. Niv Y, Fraser GM. Adenocarcinoma in the rectal segment in familial polyposis coli is not prevented by sulindac therapy. Gastroenterology 1994;107:854-7.

68. Baron JA, Cole BF, Sandler RS, et al. A randomized trial of aspirin to prevent colorectal adenomas. N Engl J Med 2003;348:891-9.

69. Benamouzig R, Deyra J, Martin A, et al. Daily soluble aspirin and prevention of colorectal adenoma recurrence: one-year results of the APACC trial. Gastroenterology 2003;125:328-36.

70. Wolfe MM, Lichtenstein DR, Singh G. Gastrointestinal toxicity of nonsteroidal antiinflammatory drugs. N Engl J Med 1999;340:1888-99.

71. Cancer IAfRo. Non-steroidal anti-inflammatory drugs; 1997.

72. Steinbach G, Lynch PM, Phillips RK, et al. The effect of celecoxib, a cyclooxygenase-2 inhibitor, in familial adenomatous polyposis. N Engl J Med 2000;342:1946-52.

73. Zell JA, Pelot D, Chen WP, McLaren CE, Gerner EW, Meyskens FL. Risk of cardiovascular events in a randomized placebo-controlled, double-blind trial of difluoromethylornithine plus sulindac for the prevention of sporadic colorectal adenomas. Cancer Prev Res (Phila Pa) 2009;2:209-12. 
74. Silverstein FE, Faich G, Goldstein JL, et al. Gastrointestinal toxicity with celecoxib vs nonsteroidal anti-inflammatory drugs for osteoarthritis and rheumatoid arthritis: the CLASS study: A randomized controlled trial. Celecoxib Long-term Arthritis Safety Study. Jama 2000;284:1247-55.

75. Arber N, Eagle CJ, Spicak J, et al. Celecoxib for the prevention of colorectal adenomatous polyps. N Engl J Med 2006;355:885-95.

76. Bresalier RS, Sandler RS, Quan H, et al. Cardiovascular events associated with rofecoxib in a colorectal adenoma chemoprevention trial. N Engl J Med 2005;352:1092102.

77. Baron JA, Sandler RS, Bresalier RS, et al. A randomized trial of rofecoxib for the chemoprevention of colorectal adenomas. Gastroenterology 2006;131:1674-82.

78. Bertagnolli MM, Eagle CJ, Zauber AG, et al. Celecoxib for the prevention of sporadic colorectal adenomas. N Engl J Med 2006;355:873-84.

79. Solomon SD, McMurray JJ, Pfeffer MA, et al. Cardiovascular risk associated with celecoxib in a clinical trial for colorectal adenoma prevention. N Engl J Med 2005;352:1071-80.

80. Rex DK, Cutler CS, Lemmel GT, et al. Colonoscopic miss rates of adenomas determined by back-to-back colonoscopies. Gastroenterology 1997;112:24-8.

81. Hixson LJ, Fennerty MB, Sampliner RE, Garewal HS. Prospective blinded trial of the colonoscopic miss-rate of large colorectal polyps. Gastrointest Endosc 1991;37:125-7.

82. Myers RE, Balshem AM, Wolf TA, Ross EA, Millner L. Adherence to continuous screening for colorectal neoplasia. Med Care 1993;31:508-19.

83. Hardcastle JD, Chamberlain JO, Robinson MH, et al. Randomised controlled trial of faecal-occult-blood screening for colorectal cancer. Lancet 1996;348:1472-7.

84. Robinson MH, Marks CG, Farrands PA, Bostock K, Hardcastle JD. Screening for colorectal cancer with an immunological faecal occult blood test: 2-year follow-up. Br J Surg 1996;83:500-1.

85. Cole SR, Young GP, Byrne D, Guy JR, Morcom J. Participation in screening for colorectal cancer based on a faecal occult blood test is improved by endorsement by the primary care practitioner. J Med Screen 2002;9:147-52.

86. Seeff LC, Nadel MR, Klabunde CN, et al. Patterns and predictors of colorectal cancer test use in the adult U.S. population. Cancer 2004;100:2093-103.

87. Zarychanski R, Chen Y, Bernstein CN, Hebert PC. Frequency of colorectal cancer screening and the impact of family physicians on screening behaviour. Cmaj 2007;177:593-7.

88. Deutekom M, van Rijn AF, Dekker E, et al. Uptake of faecal occult blood test colorectal cancer screening by different ethnic groups in the Netherlands. Eur J Public Health 2009;16:16.

89. Bonithon-Kopp C, Kronborg O, Giacosa A, Rath U, Faivre J. Calcium and fibre supplementation in prevention of colorectal adenoma recurrence: a randomised intervention trial. European Cancer Prevention Organisation Study Group. Lancet 2000;356:1300-6. 